\title{
Towards a Marxist Theory of Mediation: Contributions from Ibero-America to the Study of Digital Communication
}

\author{
Joan Pedro-Carañana \\ Complutense University of Madrid, Spain. Joan.pedro@ucm.es. \\ https://ucm.academia.edu/JoanPedroCara\%C3\%B1ana
}

\begin{abstract}
This paper presents and articulates for the first time the concept of mediation as theorised by three key scholars of the Ibero-American space, namely Manuel MartínSerrano, Luis Martín-Santos, and Jesús Martín-Barbero. This article shows that their understandings of mediation are valuable for the study of digital communication, particularly for identifying criteria that facilitate the sublation of communicative capitalism into communicative socialism. The three scholars have placed the concept of mediation at the centre of their intellectual production with the aim of breaking with mechanical Marxism, but provide differing conceptualisations and have scarcely engaged in a dialogue of knowledges. This article will articulate the complementarity of Martín-Serrano's Marxist socio-historical analysis of communication, Martín-Barbero's Latin American cultural studies, and Martín-Santos's phenomenological theorisation of mediation as the key concept of Marxist epistemology.
\end{abstract}

Keywords: mediation, communication, social change, Marxism, Ibero-American scholarship, digital socialism

Acknowledgement: This paper is part of the I+D+i project "Problemas públicos y controversias: diversidad y participación en la esfera mediática” (CSO2017-82109-R).

\section{Introduction}

The end of Franco's dictatorship and the transition to representative democracy witnessed an explosion of cultural activity and working-class struggle in Spain. In the intellectual sphere, the late 1970s and 1980s were a fecund time for Spanish critical scholarship. Some factors contributing to this intellectual production were the experiences of social struggle, the need to develop new ideas for the new socio-political system, the new contact with international scholarship, and the ideological opening of society. Of course, Spain and Latin America have strong historical, cultural and linguistic ties, but the reception of numerous Spanish exiles had contributed to further intellectual exchange and interculturality. This paper intends to contribute to this exchange by putting in dialogue the work of three scholars from the lbero-American space who have played a key part in the international flows of knowledge.

The three authors discussed in this article have shaped scholarship in the lberoAmerican space, although to differing degrees. Martín-Barbero's concept of mediation has become the dominant paradigm in Latin America and is also influential in Spain. Martín-Serrano's theory of mediation counts with a small school of thought with scholars from Spain, Mexico, Cuba and other Latin American countries. MartínSantos's work is not so influential, but is highly appreciated by Marxist thinkers in Spain. The three authors began their work in the late 1970s and 1980s, and MartínSerrano and Martín-Barbero have continued to investigate mediations until today. 
Their understanding of mediation and application to digital communication can provide valuable tools to analyse and extend digital socialism.

The paper begins with a brief profile of the authors and then discusses their work. The article synthesises the understanding of mediation of each of the authors and explains the key role this activity can play in the reproduction of (digital) capitalism as well as in the development of (digital) socialism. The three perspectives are compared and the possibilities of complementarity are identified. Because the authors address mediation from different angles, an articulation of the three approaches can reinforce one another and provide a comprehensive conceptualisation of mediation and digital socialism. Moreover, the article contextualises how the three understandings of mediation relate to Marx and Engels's works.

The work of Martín-Serrano will serve as a starting point of the articulation of perspectives because it provides a broad model for the analysis of the relations including contradictions- between the communication and social systems, and an understanding of mediation focused on media products. Martín-Barbero's work cannot be considered to follow a Marxist approach (even though it draws on Walter Benjamin), but brings to the forefront the necessary transformative agency put into practice in processes of cultural re-signification and appropriation of representations and technologies in the social system which multiply and diversify meaning. Finally, Martín-Santos provides a method to create mediations between theory and praxis by transforming knowledge into emancipatory communication and social action. In this view, mediation has a bifurcating/transformative capacity when it results from diairesis and eidos, especially when the exchange-value of commodities is sublated by the use-value.

The possibilities of complementarity can be readily observed, since MartínSerrano focuses on media mediations, while Martín-Barbero stresses the cultural mediations of receivers who also become producers, and Martín-Santos provides a theory of mediation for revolutionary praxis. The articulation of the three perspectives will allow approaching digital communication by focusing on key contradictions between the capitalist system and digital praxis based on the development of transformative narratives and the cultural and material appropriation of communicative and non-communicative means of production.

\section{Profile of the Authors}

The first author who will be discussed, Manuel Martín-Serrano (Spain, 1940-), has dedicated his academic career to the development of an encompassing theory of communication able to explain the role of communication both in the evolution of nature and in the conformation and transformation of societies. To this end, MartínSerrano has drawn on evolutionary theory, sociology, semiotics, anthropology, systems theory, epistemology, and media and communication studies.

The first sources of academic influence in Martín-Serrano's work were Marx, the Frankfurt School, Abraham Moles (cybernetics) and May 1968. Drawing on these influences, Martín-Serrano has focused on the need to develop a communication theory based on the concept of mediation which can help to identify the criteria that explain the reproduction and change of societies and of communication systems. He has always underscored the importance of theorising communication and founded the first Communication Theory department in Spain at Complutense University of Madrid.

On the other side of the Atlantic, Jesús Martín-Barbero's (Spain, 1937-) conceptualisation of mediation has become the dominant paradigm in cultural and commu- 
nication studies in Latin America. He was born in Spain in 1937, just one year after the Spanish Civil War started, and has lived in Colombia since 1963, where he founded the School of Social Communication of the Universidad del Valle (1975). His work is inspired by Walter Benjamin, Raymond Williams, semiotics, Bourdieu's sociology of culture, Michel de Certeau's productive consumption, Cultural Studies, Latin American scholarship, and Spanish anarchism.

Martín-Barbero is known for advocating for a change in scholarly attention from the media to mediations. This involves the de-mystification of the power of the media in the context of processes of multiple mediations. Martín-Barbero emphasises the power of the cultural mediations of popular subjects to re-signify discourses and create meaning.

The third author to be discussed, Luis Martín-Santos (Spain, 1921-1988), was a high-school teacher of philosophy and later on a professor of sociology of knowledge at Complutense University of Madrid. He should not be mistaken for his namesake novelist and psychiatrist who wrote Tiempo de Silencio in 1962. Martín-Santos was a Marxist militant who stirred discussions on democracy and authors like Marcuse with his high-school students during Franco's dictatorship. He was also candidate for the Spanish Communist Party in the first elections in Burgos.

Martín-Santos abhorred the functionalist theory of communication for its apocryphal consensus fetishism. He was also a cultural dynamiser and organised conferences with Henri Lefebvre, Kart Popper, and other international intellectuals. His research and teaching stays in Germany, France, and the USA put him in touch with international thought. His work on mediation aims to reach a combination of Marxism and phenomenology which could explain the complex processes involved in social revolution.

\section{Manuel Martín-Serrano: Mediations and Contradictions}

In one article in which Martín-Barbero (2007) discusses Martín-Serrano's work, the Colombian author explains the historical importance of Martín-Serrano's paradigm of mediation. In the early 1980s, researchers from Leicester (Graham Murdock and Peter Golding) where denying the pertinence of a communication theory on the grounds that communication is explained by the social formation. According to MartínBarbero, this denial actually leads to the adoption of a simplistic and deterministic understanding of the relations between communication and society in which communication is reduced to being instrumental to the social system (social control paradigm). On the other hand, Martín-Barbero notes that Martín-Serrano advocated for a communication theory which acknowledges that communication is socially produced and contributes to social reproduction, but that it also has varying degrees of autonomy and, thus, that there is possibility of change (the paradigm of dialectics).

Martín-Serrano first published on mediation in his French PhD thesis (1974). Due to difficulties with censorship, the book La Mediación Social (1977) was published in Spanish three years later. The book defines mediation as a system of rules and operations applied to any set of elements belonging to heterogeneous parts of reality to introduce an order or a design. From this point of view (see also Martín-Serrano 2004), the representations contained in media products provide a worldview, among many other possible worldviews, which influences cognitive systems and social action. In turn, the social formation influences the media system, usually to foster the reproduction of the same formation. However, media products also include models of order which negate the social order and can contribute to social change. 
Martín-Serrano (2019ab) argues that the ongoing technological revolution includes both humanising and dehumanising mediations. The humanisms propose mediations which attempt to realise the utopia of a universal access to information (the Enlightenment) and the utopia of collectively shared knowledge (communism). On the other hand, Martín-Serrano argues that dehumanising communication fosters the technocratic counter-utopia of monopoly capitalism based on positivism, social Darwinism, neoliberalism, and post-humanism.

\subsection{Historical Perspectives on the Relations between Communication and Society}

Martín-Serrano (2004) identifies three key approaches of how the relations between communication and society have been conceptualised:

- Idealism, the philosophical approach of the Enlightenment, holds that cultural/communicative changes produce change in the social totality. Transforming what is said about something, changes that something. By modifying the worldview of actors through the spreading of the Lights, society will become freer, peaceful, and equal.

- Mechanical materialism, which is the foundation of vulgar Marxism, holds the opposite view. As it is not consciousness that determines reality, but reality that determines consciousness, it is through the change of actions, and not conceptions, that reality is transformed.

- Dialectical Marxism holds that there are mutual, dynamic influences between representation and action, communication and society, structure and superstructure. Social change requires transformations in both the sphere of ideas and the material sphere.

\subsection{Dialectical Relations between Communication and Social Systems}

Martín-Serrano (2004) adopts a dialectical perspective. He argues that Marx's first works (The Economic and Philosophic Manuscripts, The Holy Family, The German Ideology and The Poverty of Philosophy) already question the validity of the programme of the Enlightenment (voluntarist idealism): in conditions of inequality, it is not possible to change society by acting only upon consciousness. The message was misunderstood by Blanqui and his followers who relegated communication and advocated for revolutionary action to transform society and, thus, consciousness (voluntarist materialism). According to Martín-Serrano, in the polemics with Blanquist communists since 1848, Marx insisted that historically false consciousness is rooted in affective needs which cannot be extirpated simply by eliminating the ideological apparatuses or by revolutionary action. Instead, consciousness and social organisation are interdependent and mutually affect each other. According to Martín-Serrano, Marx proposed a socio-historical (material and cultural; systemic) change based on solidarity and the shared use of knowledge, which allows the interrelation of theory and practice.

Martín-Serrano $(2004 ; 2007)$ combines dialectics with systems analysis to conceive the communication system and the social system as two differentiated systems which are open to one another, meaning that there are mutual influences. Each system has a partial autonomy because it has its own components, organisation and functions allowing internal changes. But each system also affects and is affected by the other system.

From this point of view, communication is socially produced. According to the law of historical necessity, communication systems are organised in each historical peri- 
od to contribute to the reproduction of the social system, i.e., they tend to adjust to the requirements of the social system for its continuity and expansion, which include reforms in the system.

However, the interrelations that take place historically may also generate disadjustments. This occurs when transformations in the systems make dominant media representations not respond to the determinations of the social system to bring about its reproduction (technological innovation, economic demands, political control, etc.).

Disadjustments sometimes refer to a contradiction, when communicative mediation exerts intense and prolonged pressure in an opposite and incompatible direction regarding the constrictions arising from society. Contradictions can be resolved in two distinct ways:

1. Most contradictions are solved with functional changes in one of the two systems, or both. Readjustments in the systems occur, but there is no change of system. It can take place when the communication system incorporates innovations that allow meeting the intellectual and/or economic needs of the social system. It may also happen that oppositional mediations contribute to society incorporating some changes, as with the civilising effect of 1968 in capitalism.

2. Less frequently, a dialectical transformation takes place, when a given system is overcome or sublated by a different system, i.e., when changing from one system to another system. Martín-Serrano identifies the following dialectical transformations of communication systems in relation to socio-historical changes: a) assembly b) by emissaries, c) by distribution networks of message, d) by mass production and distribution techniques of communication products e) by virtual networks. It should be noted that when a dialectical change takes place, the new system incorporates elements from the previous system, even though it is qualitatively a different system (see Fuchs 2015 for further discussion).

For Martín-Serrano, consensus/conflict (Conflict Studies) is not a dialectical opposition in regards to capitalism, but reproduction/revolution (Marxism) is.

\subsection{Contradictions of the Digital Era}

According to Martín-Serrano (2019ab), referential, multidirectional digital media have been replacing the mass media as the dominant model of the media. This dialectical transformation can lead either to a contradiction with regards to the social system or to the adjustment of the communication system to the functional change from industrial capitalism to global monopoly capitalism. So far, functional changes in the communication system led by corporations and states have favoured a reproductive digitalisation of face-to-face activities.

However, Martín-Serrano sees possibilities in the use of digital technologies for the transformation of the world. The utopia of universal access to information can be realised through the referential appropriation of the world which fosters the Enlightenment of all people. And the utopia of knowledge sharing can be realised through multidirectional virtualisation which socialises and diversifies communication. Usevalue can prevail over exchange-value.

\subsection{The Dialectics of Referential Appropriation}

Since many more people are involved in communicative production than in the mass media model, the data of reference (the topics and perspectives) is expanded. Many more people can provide many more representations of many more objects of reference. Martín-Serrano identifies a series of elements of the communication system 
that stand in contradiction with the requirements of capitalism to reproduce on par with the mediations that contribute to its reproduction:

- Universal access to information / Obscurantism.

- More participants can mean more plurality / Redundancy and stereotype are dominant.

- There is no need for a narrator / Algorithmic gatekeeping.

- There is the blurring of the technical division between producers and consumers of information / A technocratic class of cognitive managers.

- Reflecting events / Inventing events.

For Martín-Serrano, the utopia of universal access to diverse information intends to elevate the culture of societies in order to assure their democratic, free and peaceful functioning. It aims to contribute to human autonomy, the ability to think for oneself based on sufficient information, together with the development of the power of altruistic values, of solidarity and can be fostered with public policies and democratic control of the Internet. The global dissemination of information and knowledge can also help people to imagine how a social utopia can look like so that this image serves as a compass.

Martín-Serrano conceives mediation as a kind of Enlightenment, understood as the spreading of information, knowledge and education (the "Lights") that might eventually lead to a further utopia based on the collective production and sharing of knowledge. The latter can also be pursued through virtualisation.

\subsection{The Dialectics of Virtualisation}

Virtualisation has introduced multi-directionality, facilitating the complete communication process to take place among a multiplicity of actors. In the context of virutalisation, Martín-Serrano identifies the following dialectics:

- Multi-directionality can promote socialist relations of solidarity / It is a necessary resource for the expansion of capitalism in its purpose of materially appropriating the world.

- Multi-directionality can entail diversity / The transmission of information among many actors tends to lead to banalisation (prejudices and stereotypes) and cultural industries introduce homogeneity.

- More participants and frequency / Most of those interactions only take place in the virtual space.

- Communicative interactions are no longer constrained by spatial and temporal separations / Nationalism, chauvinism.

- Intellectual co-production / privatisation of intellectual production.

According to Martín-Serrano, the communist utopia holds that the collective ownership of communicative means of production can foster the production and exchange of knowledge based on use-value. Collectively controlled communication can also introduce diversity and mediated communication can be used to engage in physical action. He contends that there is the possibility now of globalising humanising mediations through collective creativity and shared knowledge and memory.

This utopia seeks to share knowledge of what unites, so that eventually it is possible to share the world. 
Martín-Serrano notes the successes of humanising mediations:

- The Internet was born with the purpose of making free knowledge available to everyone.

- The expansion of information open to all is unstoppable.

- The production and use of free software is increasing.

- There are growing numbers of non-profit online platforms.

- Social networks are already a real alternative for the organisation of civil society and its political mobilisations.

Martín-Serrano notes that both referential and virtual communication require greater user autonomy. As a consequence, the effectiveness of dominant mediation to maintain social control may decrease. As receivers they will exercise criticism. As producers, they will diversify social representations, calling into question consensus.

As developed below, digital mediations can play a key role in the reproduction of the capitalist system, but also in change to a communist system. The social uses of digital communication will decide if humanising mediations become dominant.

\subsection{Humanising Mediations}

Martín-Serrano argues that humanism proposes to develop our natural capacities through the use of technologies aimed at globalising Enlightenment and collective solidarity (the foundation of communism). Humanising communication brings awareness of the dignity of human beings and promotes solidarity with all human beings and groups. Communication also humanises when it serves creativity, when it is innovative and imaginative.

He considers that humanist communication (and a humanist society) is possible due to the genetic inclinations of human nature towards solidarity. Human communication evolved as another way of securing life based on altruistic values. Altruism opposes the humanising power of human nature to the impotence produced by dehumanising powers.

This leads to the conclusion that humanising mediations foster intellectual, creative and moral skills that are limited by the state of societies. Technologies are used to eliminate these limitations by transforming societies; humanising mediatons refer to socio-genetic changes.

\subsection{Dehumanising Mediations}

Martín-Serrano states that dehumanising communication links individual and collective security to ethnocentrism, xenophobia, and the imposition of force. Communication dehumanises when it limits imagination, and reproduces conformism and resignation in the face of obscurantism, which is a vision of human relations that renounces altruistic feelings and values.

Martín-Serrano argues that a key role of today's mediating institutions is to ensure that conflicts that could confront subjects with institutions and structures are transferred to interpersonal relationships. To cope with the continuing crises of socioeconomic origin, each individual is expected to "change" himself/herself as many times as necessary and as much as necessary. These mediations encourage people to adapt to living in a state of permanent crisis, without questioning the global system. These mediations are applying the technocratic counter-utopia.

According to Martín-Serrano, posthumanism promotes, willingly or not, the technocratic counter-utopia by proposing to equip humans with artificial abilities. Posthu- 
manism claims that technological and genetic interventions will eventually replace the current "homo faber" with a post-human being adapted to social control; these mediations refer to anthropogenic changes.

Martín-Serrano identifies communicative mediations that stand in contradiction to the social system and other mediations that are oriented on contributing to the reproduction of capitalism. The next section shows the complementarity of this approach with that of Jesús Martín-Barbero, whose work focuses on humanising practices of cultural mediation that introduce re-signification and diversity.

\section{Jesús Martín-Barbero: Cultural Mediations}

While Martín-Serrano focuses on what the communication system does to the people in the social system, Martín-Barbero and the Latin American school of communication give priority to what people in the social-cultural system do with the communication system.

Martín-Barbero's (1987; 1993) concept of mediation is widely understood as the cultural appropriation and re-signification of communication. This is done through agency (interpretation and production of meaning) by the receivers, who also become co-creators in the communication process. New meanings emerge from collective knowledge and interrelate with new practices. The key actors in this process are popular subjects and culture, which facilitate diversity, resistance and social change. According to Martín-Barbero the mediations of popular culture are the most important influence in defining the social meanings of communication processes and, thus, are the main counterhegemonic force. With digital convergence the possibilities have expanded for introducing diversity, interculturality, translation and sustainability.

\subsection{From Media to Mediations}

Martín-Barbero's academic efforts have focused on moving from media-centrism to the mediations that shape the communication process. In the author's own words, the analysis of mediations focuses on

processes, practices and means of communication, and in that order of importance, that is, starting from the social processes in which communication is embodied, followed by the practices in which different cultures insert communication, and thirdly the media that, from the Egyptian palimpsest and the Greek choir were transformed into book - newspaper - cinema - radio - TV Netflix (Martín-Barbero 2015, 14 [translated from Spanish to English]).

Changing the focus from the object to the process allowed research to be opened to the everyday practices of popular agents who play and an active role in the production of meaning. Martín-Barbero (2014) opposes what Raymond Williams criticised as the nefarious combination of technological determinism and cultural pessimism in critical scholarship.

For Martín-Barbero the most important mediations take place in cultural processes, and particularly popular culture, albeit this is not the only locus. He views popular culture as the main provider of mediations between society and mass culture:

Instead of starting the investigation with the analysis of the logics of production and reception, to then look for their relations of overlapping or confrontation, we propose to start from the mediations, that is, from the places from which the constraints that delimit and shape the social materiality and cultural ex- 
pressiveness of television (Martín-Barbero 1987, 23 [translated from Spanish to English]).

Even though Martín-Barbero focuses mainly on cultural mediations, he has also identified other forms of mediation which give sense to communication. As noted by Gámez-Torres (2007), in the first edition of From the Media to Mediations, MartínBarbero (1987) identifies key cultural mediations such as the habitus, families' daily life, social temporality, and cultural competencies. In the prologue to the 1998 edition, the author proposes new mediations to explain the new complexities in the constitutive relations between communication, culture, and politics. Martín-Barbero (1998, xvi) relates cultural matrices (CM) and industrial formats (IF) on the one hand and on the other hand the productive logics $(\mathrm{PL})$ and the reception or consumption competencies $(\mathrm{RC})$. The relations between $\mathrm{CM}$ and $\mathrm{PL}$ are mediated by different institutional regimes, while the relations between $\mathrm{CM}$ and $\mathrm{RC}$ are mediated by various forms of sociality. Technicities mediate between PL and IF, and rituals mediate between IF and RC.

Martín-Barbero defines technicity as the narrative aspect of the media that works as an organiser of perceptions and institutionality as the influence of economic, political and cultural interests on the media. Sociality is comprised by the everyday relations that involve non-mediatised socio-cultural mediations while rituality encompasses the different interpretations, readings, and uses of media.

\subsection{The Mediation of Popular Culture: Counterhegemonic Agency}

Martín-Barbero $(1987$; 1993) argues that there are great difficulties in applying Marxist theory, and especially Adorno's work, to Latin American reality. Martín-Barbero criticises Horkheimer's and especially Adorno's work for cultural pessimism and elitism and argues that sensitivity towards mass and popular culture and cultural diversity are key to understanding Latin American reality. A variety of historical conflicts and hybridisations among people and between mass and popular culture have created a heterogeneous cultural landscape.

Martín-Barbero also criticises Marxism for negating the value of the category of "the people". The Enlightenment placed the people at the centre of politics and Romanticism of culture. Marxism negated both through the sublation of "the popular" into the proletariat. On the other hand, anarchism combined politics and culture to affirm the validity of the popular and showed the rich possibilities of viewing the people as a historical agent of resistance and change. For anarchism, the people was an apt concept in relation to its opposition to all forms of oppression, while Marxism reduced the struggle to the relations of production. In the context of Latin America, Martín-Barbero argues, mestizo and hybrid cultures provide the key counterhegemonic mediations. In this view, identities play a key role in cultural mediation.

Against orthodox Marxism and the core of the Frankfurt School, Martín-Barbero finds inspiration in Frankfurt School associate Walter Benjamin. Martín-Barbero writes that Benjamin pioneered the understanding of popular culture not as its denial, but as experience and production. In his view, Benjamin allows us to think historically about the relationship between transformations in production conditions and changes in the space of culture, understood as the sensorium of modes of perception; the social experience.

According to Martín-Barbero, Benjamin showed that the media do not provide totalitarian alienation, but hegemony subjected to contradictions. Benjamin didn't accept that meaning had been absorbed by exchange-value. Meaning is transformed 
and leads to social realities that include both obscurantism and creativity. Benjamin, Martín-Barbero argues, opened the path to the study of the experiences of oppressed people who configure modes of resistance, grant meaning to the struggles, and are fundamental counterhegemonic actors.

\subsection{Digital Convergence and Cultural Diversity}

By looking at digitalisation from the mediations of popular culture, Martín-Barbero (2008; 2014) understands digital convergence as diversity, intercultural communication, translation, and sustainability.

\subsubsection{Diversity}

Martín-Barbero argues that the digital revolution has enhanced the possibilities of diversifying popular mediation. Communication ceases to be a process between producers and consumers. Digital convergence allows dissolving this social and symbolic barrier because it de-centres and de-territorialises the possibilities of cultural production. This leads to heterogeneity of symbolic production. As communicative production democratises on the Internet, the meanings of the mediations lived by receivers also become more diverse, which affects social action and media practices.

Martín-Barbero holds that digital convergence also favours the possibility of sustained intercultural translation. He argues that the revitalisation of identities provides a key entry point to understanding online diversity. Identities can introduce counterhegemony because of the demand for recognition, the search for meaning, and the way of belonging to and sharing the world. All identity is generated through narratives that tell stories to others. And interculturality and translation are key to facilitating diversity.

\subsubsection{Intercultural Communication}

Martín-Barbero $(2008,12)$ writes that "the Internet is the site of the total communication meeting point, a place where cultures can communicate endlessly. Internet has been a dream for mankind since quite a long". In this view, digitalisation has provided unprecedented spaces for intercultural communication on a global level. This can be observed in the ongoing process of reconfiguration of indigenous, local, and national cultures due to the intensification of communication and interaction with other national and world cultures. For example, digitalisation provides spaces which connect immigration territories with the country of origin.

According to Martín-Barbero, interculturality has nothing to do with what the media do with cultures. To exist as cultures is to exchange. Cultural diversity cannot be created from above. It can only be practiced by the diverse cultures.

Martín-Barbero notes that intercultural experiences entail a sense of danger and insecurity. They tend to be more conflictive than dialogic. However, communication can play a constitutive role when the actors acknowledge that the vitality of culture depends on its ability to communicate with others. Living cultures confront each other. They translate and are translated by other cultures.

\subsubsection{Translation}

Martín-Barbero underscores that the paradigm of translation shows the possibility of a constitutive mediation between plurality of cultures and unity of humanity. This paradigm acknowledges that there are translatable as well as indecipherable aspects of 
cultures, and that the role of each culture is to know the other cultures and re-know itself as such in the possibilities and limits of the exchange.

To affirm diversity, notes Martín-Barbero, is to affirm translatability, i.e., that there is something in common. For example, human rights, while knowing that they are perceived and ranked differently by different cultures. Even though there are some aspects which cannot be deciphered, every culture is translatable to others because it is possible to share aspects of life.

Translation brings people together because it is based on non-exteriority, nonforeignness, non-otherness. So, translation allows populations to appropriate - from the standpoint of their own culture - new knowledges and languages. The result is increased cultural hybridisation.

\subsubsection{Cultural Sustainability}

Martín-Barbero $(2008 ; 2014)$ claims that cultural sustainability is a concept in construction taken from ecological thought. When applied to culture, it is being used to study the relations between cultural difference and social inequality, and, therefore, between culture and development. This perspective holds two key ideas. First, the long temporality of cultures is in contradiction with the increasingly short temporality of objects produced and sold in the capitalist market. Second, cultural creativity in community and independent media as well as in cultural industries can play a key role in social development. The articulation of cultural value with an alternative form of development can make cultural diversity last in time.

The first idea has to be addressed, according to Martín-Barbero, outside of the Habermasian framework of dialogical consensus, in which communicative reason is deprived of the political contradictions introduced by technological and market mediations. What social change requires is to decipher the hegemony of the market and identify and facilitate the counter-hegemonies that can make cultural diversity sustainable.

The second idea requires three conditions. 1. Autonomy of the communities and social movements. 2. Political participation of citizens which is reflected in cultural policies. 3 . The ability to open one's own culture to exchange and interaction with the other cultures of the country and the world.

According to the author, digital convergence can contribute to cultural sustainability because it breaks with the artificial separations characteristic of Western epistemology. Against the excluding power of the written word, oralities and visualities acquire cultural visibility and "intertwine their memories to the imaginary of virtuality to give new meaning and new form to cultural traditions" (Martín-Barbero 2014, 26). Dualism can no longer be held in this new communication environment. The appropriation of the hypertext means putting together texts, sounds, images, and videos in an interactive way that expands the possibilities of combining different temporalities, reading and writing, the book and the audio-visual, knowing and doing, arts and sciences, culture and technique, reason and imagination, aesthetic passion and political action.

The Internet can also facilitate cultural sustainability by providing new spaces that are configured by social movements, cultural communities, and community media. Subaltern sectors are increasingly appropriating new technologies to build counterhegemony all throughout the world. The political context for interculturality can be renewed by networks which connect cultural workers and artists with territorial institutions and social organisations. A new public sphere can emerge with new modalities of cultural, artistic, scientific and political communities which benefit from digitalisa- 
tion. These communities are engaged in the decisive political struggle for cultural visibility.

Martín-Barbero advocates for implementing public policies for cultural convergence that set the grounds for a new cognitive economy focused on human rights. The regulatory frameworks should have both a local and a global scope at the same time. In his opinion, the priority is to explore the strategic potential of digital convergence for the socio-cultural integration of the Ibero-American space that is in construction. The survival of diversity depends, according to the author, on a new global cultural institutionality capable of interpellating global organisations. This new institutionality will only arise from a new type of relationship of culture with the nation-state. This transformation does not involve replacing the state, but citizens reinstating or reinstitutionalising the state so that it focuses on interacting with the local communities and the new world actors.

Martín-Barbero notes the contradictory nature of the digital revolution: it is a source of inequalities, but also a source of citizen empowerment. The connective and interactive model of net communication facilitates cultural mediations which introduce diversity and help people get associated, participate in society and engage in creative expression.

If Martín-Serrano writes about the features of humanising and dehumanising mediations, Martín-Barbero argues that the possibilities of humanisation depend on the mediations arising from popular culture. And, as developed in the next section, Martín-Santos provides a specific guide, a method for the development of humanising or communist mediations both in the communication and the social systems.

\section{Luis Martín-Santos: Mediations between Theory and Praxis}

Luis Martín-Santos's work adds to the other two perspectives a method to produce mediations to articulate revolutionary theory and praxis. Martín-Santos was a specialist in Husserlian phenomenology and aimed to combine it with Marxism, particularly through the concept of mediation. According to Martín-Santos, Marxism provides a framework based on historical materialism and dialectics that can be strengthened by phenomenologically detailing the way in which the world becomes present in subjectivity. Thus, phenomenology allowed him to think revolution at the level of meaning.

Martín-Santos's $(1976 ; 1977 ; 1988)$ work can be interpreted in today's context to define communicative communism as mediations based on diairesis (rupture) and totalisation (eidos). These mediations are conducted by the digital proletariat for the abolition of the private property of the means of communicative and noncommunicative production (classless society). This model of communication would be characterised by confrontation of ideas and dialogue, as well as by the primacy of use-value and diversity.

According to Martín-Santos, the ideas of mediation, diairesis, and totalisation can be found throughout Marx and Engels's works. However, he notes that mediation is more prominent in The German Ideology (Marx and Engels 1846/2010), diairesis in The Economic and Philosophic Manuscripts (Marx 1844/1975a), and totalisation in Capital (Marx 1867/1990).

\subsection{Mediation}

Martín-Santos (1976) claims that Marx and Engels used the idea of mediation much more than they named it. He notes that often they did not differentiate it from the crude concept of cause, but that the idea of mediation can be observed in their use of terms such as connection, root, or result. According to Martín-Santos, a Marxist un- 
derstanding of mediation points to a complex, multi-faceted process that produces social change. He was particularly interested in the mediations that can articulate theory and praxis to bring about social sublation, i.e., for the emergence of a communist society.

This understanding of mediation is opposed to both idealistic subjectivism and Lenin's objectivist theory of reflection, since both theories are based on the mechanical and deterministic coincidence of the subject with the real world. Only the processes of mediation can facilitate an articulation of revolutionary theory and praxis. The author argues that Marx and Engels viewed consciousness and social relations as interdependent.

Martín-Santos (1977) refers to the criticism of Hegel in The German Ideology (Marx and Engels 1846/2010): the superstructure is not autonomous; consciousness cannot be understood as the result of the autonomous force of the spirit, but as a social fact. If for Hegel the Idea creates life, for Marx consciousness and theory have their roots in praxis while serving to correct it.

Martín-Santos notes that historical materialism underscores the importance of material mediations in consciousness. Moreover, unlike vulgar materialism, he holds that Marx's dialectical conception of history views ideas as a mediating power. He further clarifies that, in spite of some expressive excesses, the works of Marx and Engels (for example, The Holy Family, Marx and Engels 1845/1975) identify interrelations between thought and reality and conclude that theory can only be realised as a realisation of necessities.

From a dialectical point of view, mediations between ideas and praxis are found in revolutionary processes: praxis is incorporated into theory and ideas become material power when they are appropriated by the working class (Marx 1844/1975b).

Martín-Santos $(1976,30)$ posits three laws to understand the mediations between theory and praxis:

1. The law of non-interruption indicates that all elements are interrelated parts of a social formation. No element exists by itself in isolation but as part of a chain of mediations that limit and enable each other.

2. The law of alternative mediation opposes a priori and mechanical approaches that reduce social reality to crude relations of cause and effect in which some elements are mere reflection of others. Even though historical materialism demonstrates the determining effect of matter in the last instance, according to this law, in any given social process there is no a priori hierarchy between economy and culture, no exclusive foundational principle. Instead of strict determinism, there is polivalence. There is intellectual democratisation.

3. The law of revolution as the generalisation and intensification of mediations suggests that the programme of historical materialism aims to find and promote the mediations that allow unifying theory and praxis.

Martín-Santos (1977) aims to provide analytical tools to understand and foster mediations for revolutionary subjectivisation and material transformation. He understands mediation as the result of a double dialectical movement that operates at both cognitive and metaphysical levels as a creator of continuity in the discontinuity of being and thought. The phase of negativity which renounces to the immediate is understood as a diairesis, a rupture with revolutionary potential. And the movement of sublation is understood as a totalisation which involves recuperation and sublimation.

Martín-Santos clarifies that diairesis and totalisation are different to an antithesis and synthesis. Antithesis and synthesis are based on a logical determination while 
diaresis and totalisation are based on an anthropological determination in which the subject gets involved in social transformation and is transformed.

\subsection{Diairesis}

Martín-Santos understands diairesis as a rupture that produces discontinuity in a fact and a concept (or theory) based on its contradictions or internal incompatibilities. If bourgeois thought presents both social processes and concepts as a unity with continuity, Marxism discovers the internal fissures and acts to produce a profound tear. Thus, in diaresis, Marxism aims to identify and unveil hidden alienations. By demonstrating the contradiction in a concept or fact, the diairesis sheds light on a rupture that cannot be reabsorbed in the original intended unity. When the fictitious unity is revealed, the process of bifurcation is irreversible and consciousness becomes revolutionary. A concept no longer means the same as before. Dialectics has made it critical. Therefore, diairesis is a method of awareness regarding the material world and a guide for praxis.

Martín-Santos provides several examples which can serve as a guide for theory and praxis:

- Social totality is divided by class struggle (Communist Manifesto). Likewise, the Hegelian concept of "man" as a theoretical unit cannot be sustained when Marxist diairesis is applied, which shows the alterity of the proletarian and the bourgeoisie. The human being is also divided into being and history, discontinuity and continuity, and the proletarian is made up of both physical and spiritual needs.

- Misery is not only misery, Marx argued in his letter to Schweitzer about Proudhon. The concept hides a contradiction, for misery is lack but also strength, repression and subversion.

- The notion of order from the point of view of a formal analysis has a positive meaning. However, diairesis discovers the repressive dimension of order as well as an empowering dimension that tries to create the conditions for channelling the revolutionary protest.

- Use-value and exchange-value of commodities: Martín-Santos contends that this is possibly the most important example of diairesis provided by Marx. In capitalism, the quantitative predominates over the qualitative. The fetishism of commodities is imposed, which hides the social relations of production between people (exploitation) for the benefit of economic relations between objects. The worker experiences alienation in exchange. There is a humanisation of the product and an objectification and dehumanisation of the producer.

- Other diairesis can be observed in society, which is broken in theory and praxis, and structure and superstructure.

\subsection{Totalisation}

After diairesis, the next movement in the mediation process is totalisation or convergence. The author argues that the objective is to reach a real unity of the opposites (reconciliation) in a classless society by abolishing the private ownership of the means of production. Totalisation acts upon heterogeneous elements. It involves the convergence of theory and praxis, i.e., the realisation of Marxist philosophy and the abolition of the proletariat and class contradictions (Marx 1844/1975b). Revolution as a totalisation keeps the continuity of working class struggle in a discontinuity regarding the social formation. As Marx (1867/1990) explains in Capital, collective ownership fosters use-value and brings an end to commodity fetishism. 
Martín-Santos provides a method to develop totalisations by giving meaning to and articulating the diairesis elements. This method is based on variations that allow for constructing eidos or polemical ensembles. Specifically, eidos are mediations between theory and praxis that allow their reunion.

This method looks at a topic from different points of view and explores all possible paths. A variety of aspects of the topic that initially appear to be independent merge in a figure (eidos). This eidos, with its internal interrelations and tensions, provides the concrete meaning of the topic. While concepts are static and peaceful, eidos are dynamic, complex, dialectical and with great cognitive strength, which makes them effective mediators to understand and transform reality. Eidos provide the mediation needed for scientific thought.

Martín-Santos notes that Marx (1844/1975b) used this method continually but especially to describe the proletariat in the introduction to Critique of Hegel's' Philosophy of Right. The proletariat was defined here as universality of suffering, sufferer of total injustice, artificially impoverished, product of social dissolution, negativity, possessor of a title of human being, and universal emancipator.

Martín-Santos applies the method of eidos to explain the sense of revolution from different, albeit complementary points of view:

- Social: unequal development of the revolutionary forces; processes to achieve harmony and share a programme for a life in common.

- Economic: functionalisation of wealth; revolutionary energy can improve the economy by fostering use-value and distributing property.

- Cultural: counterculture aims to refute existing ways of life and implement problematic cultural principles which have not been used yet.

- Political: dispersion (not transfer) of power.

- Anthropological: new behaviours; recovery of vitality.

- Historical: a change in the goals and course (not a mere acceleration).

- Ideological/philosophical: the loss of magic of dominant ideas (de-naturalisation).

Developing communism would require mediations in all dimensions of reality as a tensor unity (eidos). However, Martín-Santos notes that this eidos is still too abstract and proposes a concrete phenomenology of the dialectics of confrontation and dialogue.

\subsection{Communication}

Martín-Santos understands the role of communication as follows:

The technique of confrontation allows the socialisation of knowledge through adjustment, guesswork, regression and other movements of ideas. Discrepancy with others allows the discovery of one's own thought. Together with dialogue, confrontation allows the emergence of the epistemic subject, which keeps thought alive, socialist, and shareable.

Dialogue means receiving and responding to ideas from others who have had direct experience. "I think" turns into "we think" and "my truth" becomes "our truth". It allows the proletariat to objectivise reality collectively. This real dialogue is continued and bifurcated by transcendental dialogue with the classics. Moreover, there is dialogue about the revolution but also revolution as dialogue (mediating model and mediated model). Dialogue should focus on the concrete, which is contradictory and attached to praxis. Concrete reality is the logos of language and revolution. 
Martín-Santos contends that in The German Ideology Marx (1846/2010) explains that language plays a key mediating role in society because it is real, practical consciousness and always appears as a relation with other people and with other words. It is individual and social. The production of ideas is a language and production is the language of reality.

Even though new technologies are mainly used as means for diversion, they can also be used to raise class consciousness. Communication can give meaning to the revolution and guide action through a renewed eloquence. Instead of adopting a contemplative way of knowing, a Marxist use of digital media involves adopting a theoretical-practical global attitude to confront capitalism. The point is not to de-codify, but to produce communication.

Transformative communication and action should be grounded in internal democracy and camaraderie as mediations that facilitate the reproduction of the socialist project. A Marxist party plays a key role, just as the youth and collective intellectuals, but the working class is in charge of leading the process. Since the new proletariat is formed by the decomposition of other classes, the origin of today's proletariat is diverse and heterogeneous, and includes all the lucid people who are resisting capitalistic power.

In synthesis, Martín-Santos describes a complex process of mediation between theory and praxis, superstructures and structures, to produce in an active and inventive way new ideas and material changes. Mediations involve a variety of actors and factors, which foster rupture and transformed reunion in the development of a communist society and communication system.

\section{Conclusion}

Mediations play a key role in the reproduction of monopoly capitalism, but they are also being used to move towards what could be called communicative communism.

Martín-Serrano notes the contradiction between a multidirectional digital system capable of turning most people into producers of communication and expanding the data of reference with the need of capitalism to concentrate and control communication for reproductive ends. In this context, de-humanising (technocratic) mediations try to obscure links of solidarity, while humanising mediations count with the technical possibility of the world-wide dissemination of information and sharing of knowledge.

Martín-Barbero complements this perspective by looking at the cultural mediations of popular subjects in the counter-hegemonic appropriation and re-signification of communication messages and technologies. Martín-Barbero argues that digital convergence provides for the first time in history technological means to achieve the utopia of diversity through interculturality, translation, and sustainability.

Finally, Martín-Santos adds a normative guide to action. He conceives mediation as the theory-praxis (both material and communicative) that produces diairesis (ruptures) and totalisations leading to the abolition of the private means of productions. Communication plays a key role in the development of socialist narratives and the exchange of theory and praxis, the confrontation of ideas, international dialogue, and the expansion of use-value.

The work of the three authors allows addressing the study of mediations as a complex totality with interconnected parts. Communicative communism can thus be characterised as being based on critical-transformative mediations that operate both in the communication system and the social system to produce ruptures and transform the cultural superstructure that contributes to the emancipation of consciousness in interdependence with the re-appropriation of the means of production by the 
heterogeneous working class and other popular actors. They can operate on a global level to disseminate information, facilitate the counterhegemonic enjoyment of popular culture, and contribute to the collective production and sharing of creative work in multidirectional flows of communication. This international dialogue can only be achieved by introducing diversity, which has to be guided by interculturality, which, in turn, is facilitated by the paradigm of translation. These mediations should contribute to reducing and eventually eliminating technical and social division of labour. They aim to connect theory and praxis in order to create sustainable conditions of autonomy (freedom) and equality that allow the unfolding of altruistic values and the expansion of use-value.

\section{References}

Fuchs, Christian. 2017. Social Media: A Critical Introduction. London: Sage.

Gámez Torres, Nora. 2007. El Paradigma de la mediación: Crítica Y Perspectivas. Mediaciones Sociales 1 (January): 195-213.

Martín-Barbero, Jesús. 2015. ¿Desde dónde pensamos la comunicación hoy?. Chasqui. Revista Latinoamericana de Comunicación 0 (128): 13 - 29.

Martín-Barbero, Jesús. 2014. Diversidad en convergencia. MATRIZes 8 (2): 15-33. https://doi.org/10.11606/issn.1982-8160.v8i2p15-33

Martín-Barbero, Jesús. 2008. Diversidad cultural y convergencia digital. IC Revista Científica de Información y Comunicación 5: 12-25.

Martín-Barbero, Jesús. 2007. Paradigmas de Comunicación: Un Mapa Con Memoria Latinoamericana. Mediaciones Sociales 1: 235-260.

Martín-Barbero, Jesús. 1993. Communication, Culture and Hegemony: From the Media to Mediations. London: Sage.

Martín-Barbero, Jesús. 1987. De los medios a las mediaciones. Barcelona: Gustavo Gili.

Martín-Santos, Luis. 1988. Mediación. In Terminología científico-social. Aproximación crítica, edited by Román Reyes, 595-600. Barcelona: Anthropos.

Martín-Santos, Luis. 1977. Teoría marxista de la revolución. Madrid: Akal.

Martín-Santos, Luis. 1976. Una epistemología para el marxismo. Madrid: Akal.

Martín-Serrano, Manuel. 2019a. When and how did the Theory of Communication become scientific. Comunicación Y Sociedad, June: 1-23. https://doi.org/10.32870/cys.v2019i0.7477

Martín-Serrano, Manuel. 2019b. Communication and information in a virtualising world. Foreseeable developments and functions. Comunicación y Sociedad, June: 1-29. https://doi.org/10.32870/cys.v2019i0.7478

Martín-Serrano, Manuel. 2007. Teoría de la Comunicación. La comunicación la vida y la sociedad. Madrid: McGraw-Hill.

Martín-Serrano, Manuel. 2004. La Producción Social de Comunicación. Madrid: Alianza.

Martín-Serrano, Manuel. 1977. La mediación social. Madrid: Akal.

Martín-Serrano, Manuel. 1974. L'ordre du monde á travers la TV. Lille, France: Presses Universitaires.

Marx, Karl. 1867/1990. Capital: A Critique of Political Economy: Volume 1. London: Penguin.

Marx, Karl. 1844/1975a. The Economic and Philosophic Manuscripts of 1844. In Marx \& Engels Collected Works Vol 3: 1843-1844, 229-346. London: Lawrence \& Wishart.

Marx, Karl. 1844/1975b. Critique of Hegel's' Philosophy of Right. In Marx \& Engels Collected Works Vol 3: 1843-1844, 3-129. London: Lawrence \& Wishart.

Marx, Karl and Frederick Engels. 1846/2010. The German Ideology. In Marx and Engels Collected Works, Volume 5: 1845-47, 19-581. London: Lawrence \& Wishart.

Marx, Karl and Frederick Engels. 1845/1975. The Holy Family. In Marx and Engels Collected Works, Vol. 4: 1844-45, 5-211. London: Lawrence \& Wishart. 


\begin{abstract}
About the Author
Joan Pedro-Carañana

Complutense University of Madrid. He is interested in the role of communication, education and culture in the reproduction and transformation of societies. He is co-editor of Talking Back to Globalization: Texts and Practices (Peter Lang) and The Propaganda Model Today: Filtering Perception and Awareness (University of Westminster Press).
\end{abstract}

